\title{
QUIZ
}

CORRECT ANSWER TO THE QUIZ. CHECK YOUR DIAGNOSIS

\section{CANALICULAR ADENOMA OF THE UPPER LIP}

\section{METACHRONOUS (MULTIFOCAL) CANALICULAR ADENOMA OF THE UPPER LIP: A CASE REPORT OF AN UNUSUAL FINDING}

Dariusz Tyralik ${ }^{1}$, Aneta Dzierwa-Gawron ${ }^{2}$, Janusz Ryś ${ }^{3}$

\author{
${ }^{1}$ Department of Pathology, Edward Szczeklik Memorial Specialist Hospital, Tarnow, Poland \\ 2Outpatient Department of Maxillofacial Surgery SPZOZ Tarnow, Poland \\ ${ }^{3}$ Department of Tumor Pathology, Centre of Oncology - Maria Skłodowska-Curie Memorial Institute, \\ Krakow Branch, Poland
}

\begin{abstract}
We report a peculiar case of canalicular adenoma of the upper lip in a 57-year-old woman, presenting as two distinct asymptomatic nodules diagnosed and treated surgically within a 2-year period.
\end{abstract}

Key words: canalicular adenoma, histology, immunohistochemistry.

\section{Introduction}

Canalicular adenoma (CA) is a distinctive tumor occurring almost exclusively in the upper lip [1-3]. It is a relatively rare neoplasm, but it is the second (or the third) most common tumor among benign tumors of minor salivary glands [4, 5]. A few cases of multiple foci of CA have been reported in the literature [6-12]. We present herein a new case of multifocal canalicular adenoma of the upper lip, involving a 57-year-old woman, and discuss histological and immunohistochemical characteristics of the tumor.

\section{Case report}

A 57-year-old female patient presented to the Dentistry Department with a tumor on the upper lip. Macroscopic examination revealed a well-circumscribed, smooth, firm, round nodule with a diameter of $0.5 \mathrm{~cm}$ (Fig. 1). Histologically, it was composed of anastomosing duct-like or trabecular structures lined with a single or double layer of columnar cells (Fig. 2), which were immunoreactive to cytokeratin (Fig. 3), CD117 (Fig. 4) and S100 protein (Fig. 5). The histological texture and immunohistochemical characteristics of primary tumor, localized in the neighborhood, excised 2 years earlier, were similar to the microscopic picture of the presented neoplasm. The patient is currently free of disease 6 months after surgical excision of the tumor.

\section{Discussion}

Canalicular adenoma is a benign tumor which comprises $1 \%$ of salivary gland neoplasms. However, among intraoral minor salivary gland tumors it constitutes approximately $5.6 \%-11.7 \%$ of all studied cases [4, 5, 13-15].

It occurs typically (in about $90 \%$ of cases) in the upper lip [1-3] and buccal mucosa [13] of individuals usually over 60 years old. Infrequently it is found on the palate $[16,17]$ and in the parotid gland $[8,18,19]$.

A few cases of multiple foci of CA have been reported in the literature. Most of them appeared as synchro- 


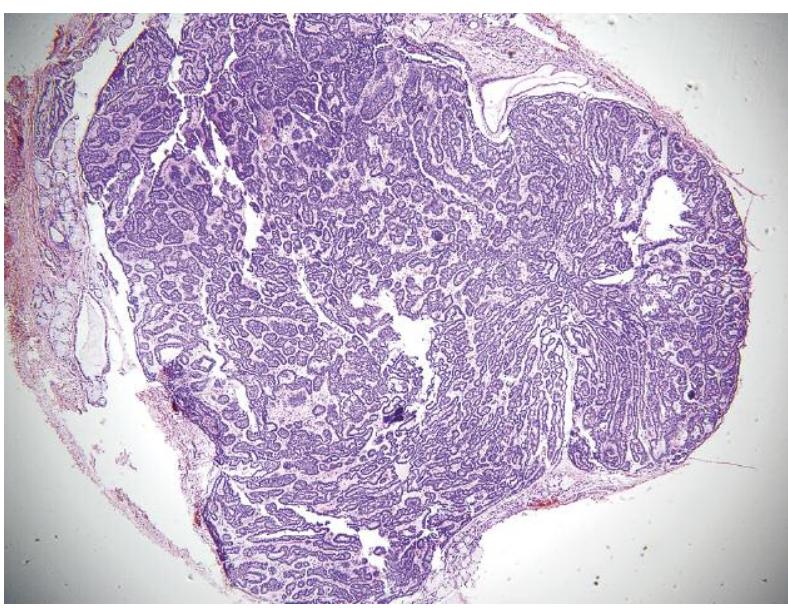

Fig. 1. Histological picture of the tumor on the upper lip. HE. Low magnification

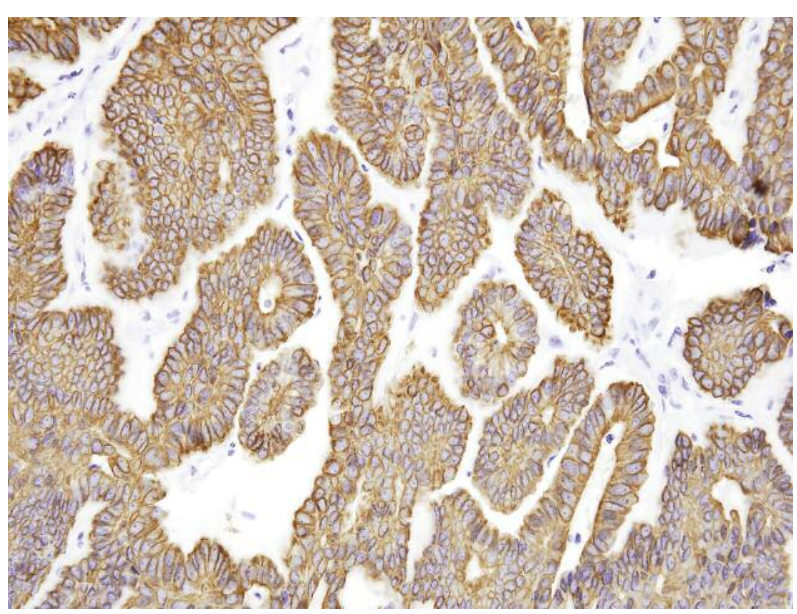

Fig. 3. Immunohistochemical reaction to cytokeratin 7

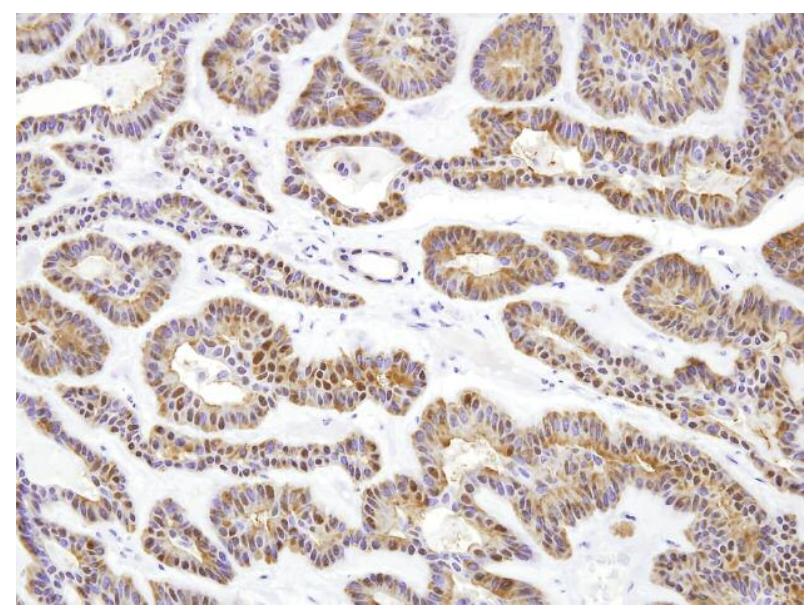

Fig. 5. Immunohistochemical reaction to $\mathrm{S} 100$ protein

nous, sometimes bilateral changes (Table 1). The exceptionally rare multifocal cases were presented by Rousseau [10] and by Khullar et al. [12]. The first author described a case that manifested with 13 clinically discrete tumor masses involving the upper lip and anterior buccal mucosa. In addition to the

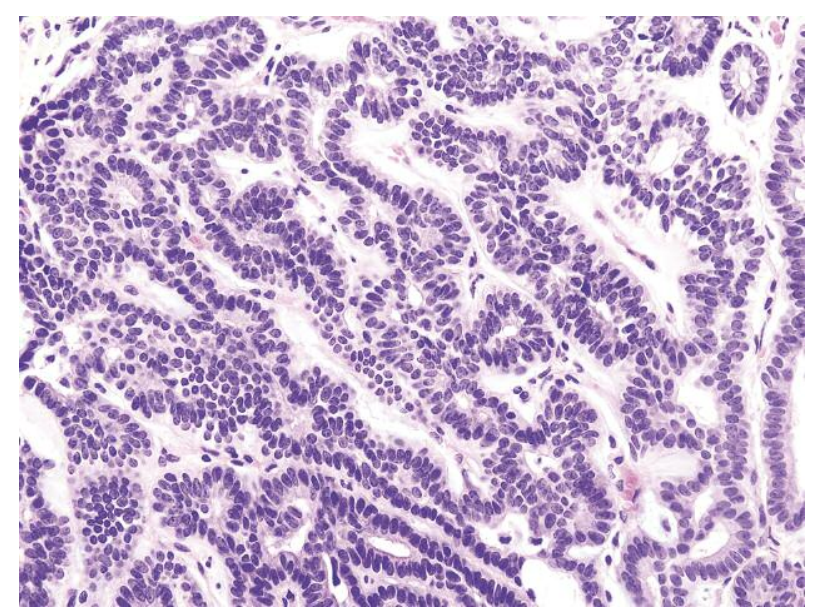

Fig. 2. Histological picture of the tumor on the upper lip. HE. High magnification

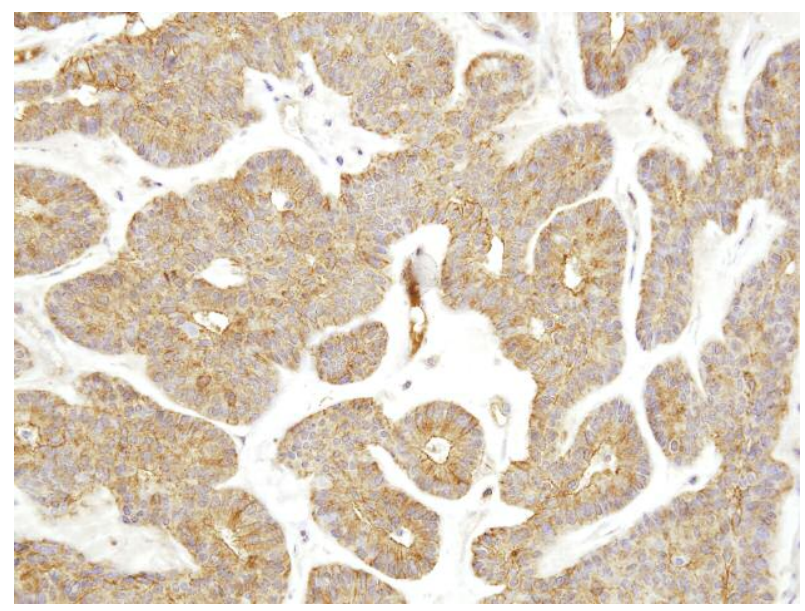

Fig. 4. Immunohistochemical reaction to CD117

clinical nodules, there were microscopic foci of tumor cells in the adjacent normal-appearing salivary gland tissue surrounding the tumors [10]. Khullar $e t$ al. presented a patient who had multiple canalicular adenomas in the upper lip and adjacent oral mucosa. A few months after these had been excised, several more tumors of the same type developed. He named the lesions adenomatosis of minor salivary glands [12].

There is some disagreement among investigators about whether canalicular adenoma is a unique entity. This tumor has often been referred to as a variant of basal cell adenoma. However, the World Health Organization's latest histological classification of salivary gland tumors [20] recognizes it as a separate entity under the broader heading of monomorphic adenoma, which is not related to any of the subtypes of basal cell adenomas.

Basal cell adenoma is a benign epithelial neoplasm with a uniform histological appearance dominated by basaloid cells. These cells may be distributed in various arrangements as solid, trabecular, tubular and membranous [21]. In contrast, canalicular adenoma is char- 
Table I. Multiple canalicular adenomas of minor salivary glands. Data from literature

\begin{tabular}{|c|c|c|c|c|c|c|c|}
\hline No & AGE & SEX & LOCATION & $\begin{array}{l}\text { TUMORS' } \\
\text { CHARACTERISTICS }\end{array}$ & $\begin{array}{l}\text { RECURRENT } \\
\text { TUMOR (MO) }\end{array}$ & AUTHOR (YEAR) & $\begin{array}{l}\text { REFERENCE } \\
\text { NO. }\end{array}$ \\
\hline 1 & 78 & $\mathrm{~F}$ & upper lip & $\begin{array}{l}2 \text { nodules on the right side } \\
\text { and another } 2 \text { lesions on the } \\
\text { left side }\end{array}$ & Yes (12) & $\begin{array}{l}\text { Mansueto et al. } \\
(2009)\end{array}$ & [6] \\
\hline 2 & 76 & $\mathrm{~F}$ & upper lip & $\begin{array}{l}2 \text { distinct masses on the right } \\
\text { and left side of the upper lip, } \\
0.8 \mathrm{~cm} \text { and } 1.1 \mathrm{~cm} \text { in diameter, } \\
\text { respectively }\end{array}$ & n.d. & $\begin{array}{l}\text { Yoon et al. } \\
(2006)\end{array}$ & [7] \\
\hline 3 & 26 & $\mathrm{M}$ & $\begin{array}{l}\text { parotid } \\
\text { glands }\end{array}$ & $\begin{array}{l}\text { lobulated masses in both } \\
\text { parotid glands }\end{array}$ & n.d. & $\begin{array}{l}\text { Liess et al. } \\
(2006)\end{array}$ & [8] \\
\hline 4 & 68 & $\mathrm{~F}$ & upper lip & $\begin{array}{l}22 \text { nodules up to } 2 \mathrm{~cm} \text { in } \\
\text { diameter }\end{array}$ & No (48) & $\begin{array}{l}\text { Queiroz et al. } \\
(2004)\end{array}$ & [9] \\
\hline 5 & 64 & $\mathrm{M}$ & $\begin{array}{l}\text { upper lip \& } \\
\text { buccal } \\
\text { mucosa }\end{array}$ & $\begin{array}{l}13 \text { submucosal nodules up } \\
\text { to } 1.1 \mathrm{~cm} \text { in diameter }\end{array}$ & No (6) & $\begin{array}{l}\text { Rousseau et al. } \\
\text { (1999) }\end{array}$ & [10] \\
\hline 6 & 75 & $\mathrm{~F}$ & $\begin{array}{l}\text { buccal } \\
\text { mucosa }\end{array}$ & $\begin{array}{l}2 \text { distinct masses in the left } \\
\text { cheek mucosa and the third } \\
\text { lesion appeared } 9 \text { months later }\end{array}$ & Yes $(9,21)$ & $\begin{array}{l}\text { Nelson et al. } \\
(1995)\end{array}$ & [11] \\
\hline 7 & 59 & $\mathrm{M}$ & $\begin{array}{l}\text { upper lip \& } \\
\text { buccala }\end{array}$ & $\begin{array}{l}6 \text { lesions of the buccal mucosa } \\
\text { and one - the largest, } 1.5 \mathrm{~cm} \\
\text { in diameter in the upper lip; } \\
\text { next } 14 \text { new nodules confined } \\
\text { to the upper lip and buccal mu } \\
\text { were excised } 1 \text { and } 6 \text { month la }\end{array}$ & n.d. & $\begin{array}{l}\text { Khullar et al. } \\
\text { (1992) }\end{array}$ & [12] \\
\hline
\end{tabular}

F-female, $M-$ male, n.d. - no data available

acterized by a complex cellular pattern of anastomosing duct-like, trabecular or papillary-like structures lined by a single layer of tall columnar epithelial cells embedded in a loose, fibrous, and highly vascular connective tissue stroma [21-23]. What is more, the results of several immunohistochemical studies showed a distinct immunoprofile for both neoplasms [21].

Canalicular adenoma needs to be distinguished from ductal and epithelial-rich pleomorphic adenomas, basaloid or purely myoepithelial tumors, and especially from adenocarcinomas. One must remember that canalicular adenoma and both polymorphous low-grade adenocarcinoma (PLGA) as well as adenoid cystic carcinoma (ACC) may share some histological characteristics that can cause difficulties in their differentiation, and the over-diagnosis of malignant neoplasm may result in unjustified radiotherapy or extensive and aggressive surgery.

Immunohistochemistry can be helpful in the diagnosis of minor salivary gland neoplasms. The cells of the canalicular adenoma showed an immunohistochemical profile that indicates an excretory duct origin: most of these cells were immunoreactive to pancytokeratins (AE1/AE3), and S-100 protein, but were negative for smooth muscle actin (SMA), vimentin and CK13 or CK14 [23-25]. Rare focal staining with antiepithelial membrane antigen was also noted [25]. Canalicular adenoma did not demonstrate p63 staining, consistent with this tumor's putative luminal duc- tal cell differentiation. Contrarily, nuclear p63 reactivity was uniformly positive in polymorphous low-grade adenocarcinoma. Positive reactivity was also identified in the majority of cases of adenoid cystic carcinoma primarily in the nonluminal myoepithelial-like cells surrounding luminal cells. All basal cell adenomas of parotid origin stained strongly for p63, too. However, none of the basal cell adenomas originating in the upper lip expressed p63 [26]. Vimentin is an important marker to differentiate between canalicular adenoma and polymorphous low-grade adenocarcinoma; vimentin is only expressed by PLGA [27]. Additionally, the pattern of GFAP immunoreactivity may be an adjunct to differential diagnosis of canalicular adenoma and PLGA. Ninety-six percent of canalicular adenomas demonstrated a distinctive linear immunoreactive pattern among cells in proximity to the connective tissue interface [28].

This tumor has an excellent prognosis after conservative surgical treatment in all locations [24]. However, patients with canalicular adenoma may need a longer follow-up due to its tendency towards multifocal occurrence and late (up to 11 years) recurrence [29].

The authors declare no conflict of interest. 


\section{References}

1. Nelson JF, Jacoway JR. Monomorphic adenoma (canalicular type). Report of 29 cases. Cancer 1973; 31: 1511-3.

2. Triantafyllou A, Coulter P, Scott J. Phenotypes in canalicular adenoma of human minor salivary glands reflect the interplay of altered secretory product, absent neuro-effector relationships and the diversity of the microenvironment. Histopathology 1999; 35: 502-16.

3. McMillan MD, Smith CJ, Smillie AC. Canalicular adenoma: report of five cases with ultrastructural observations. J Oral Pathol Med 1993; 22: 368-73.

4. Yih WY, Kratochvil FJ, Stewart JC. Intraoral minor salivary gland neoplasms: review of 213 cases. J Oral Maxillofac Surg 2005; 63: 805-10.

5. Waldron CA, el-Mofty SK, Gnepp DR. Tumors of the intraoral minor salivary glands: a demographic and histologic study of 426 cases. Oral Surg Oral Med Oral Pathol 1988; 66: 323-33

6. Mansueto G, Falleti J, De Cecio R, et al. Synchronous bilateral multifocal canalicular adenoma: a case report of an unusual finding. Clin Exp Dermatol 2009; 34: e587-9.

7. Yoon AJ, Beller DE, Woo VL, et al. Bilateral canalicular adenomas of the upper lip. Oral Surg Oral Med Oral Pathol Oral Radiol Endod 2006; 102: 341-3.

8. Liess BD, Lane RV, Frazier S, et al. Bilateral canalicular adenoma of the parotid gland. Arch Otolaryngol Head Neck Surg 2006; 132: 339-41.

9. Queiroz LM, da Silveira EJ, Silva Arruda Mde L, et al. A rare salivary gland neoplasm: multiple canalicular adenoma; A case report. Auris Nasus Larynx 2004; 31:189-93.

10. Rousseau A, Mock D, Dover DG, et al. Multiple canalicular adenomas: a case report and review of the literature. Oral Surg Oral Med Oral Pathol Oral Radiol Endod 1999; 87: 346-50.

11. Nelson ZL, Newman L, Loukota RA, et al. Bilateral multifocal canalicular adenomas of buccal minor salivary glands: a case report. Br J Oral Maxillofac Surg 1995; 33: 299-301.

12. Khullar SM, Best PV. Adenomatosis of minor salivary glands. Report of a case. Oral Surg Oral Med Oral Pathol 1992; 74: 783-7.

13. Maamouri F, Bellil K, Bellil S, et al: Canalicular adenoma of buccal mucosa. Pathologica 2007; 99: 69-70.

14. Pons Vicente O, Almendros Marqués N, Berini Aytés L, et al. Minor salivary gland tumors: A clinicopathological study of 18 cases. Med Oral Patol Oral Cir Bucal 2008;13: E582-8

15. Buchner A, Merrell PW, Carpenter WM. Relative frequency of intra-oral minor salivary gland tumors: a study of 380 cases from northern California and comparison to reports from other parts of the world. J Oral Pathol Med 2007; 36: 207-14.
16. Smullin SE, Fielding AF, Susarla SM, et al. Canalicular adenoma of the palate: case report and literature review. Oral Surg Oral Med Oral Pathol Oral Radiol Endod 2004; 98: 32-6.

17. Werder P, Altermatt HJ, Zbären P, et al. Canalicular adenoma of a minor salivary gland on the palate: a case presentation. Quintessence Int 2009; 40: 623-6.

18. Rossiello R, Rossiello L, De Simone S, et al. Canalicular adenoma of the parotid gland: a case report. Anticancer Res 2003; 23: 4101-3.

19. Butler C, Kulendra KN, Menon G, D'Souza AR. Canalicular adenoma: a case report of an unusual parotid lesion. BMJ Case Rep 2009; 2009: pii: bcr10.2008.1072.

20. World Health Organization Classification of Tumours. Pathology and Genetics of Head and Neck Tumours. Barnes L, Everson JW, Reichart P (eds). IARC Press, Lyon 2005.

21. Machado de Sousa SO, Soares de Araújo N, Corrêa L, et al. Immunohistochemical aspects of basal cell adenoma and canalicular adenoma of salivary glands. Oral Oncol 2001; 37: 365-8.

22. Hruban RH, Erozan YS, Zinreich SJ, et al. Fine-needle aspiration cytology of monomorphic adenomas. Am J Clin Pathol 1988; 90: 46-51

23. Matsuzaka K, Murakami S, Shimono M, et al. Canalicular adenoma arising in the upper lip: review of the pathological findings. Bull Tokyo Dent Coll 2004; 45: 229-33.

24. Pereira MC, Pereira AA, Hanemann JA. Immunohistochemical profile of canalicular adenoma of the upper lip: a case report. Med Oral Patol Oral Cir Bucal 2007; 12: E1-3.

25. Ferreiro JA. Immunohistochemical analysis of salivary gland canalicular adenoma. Oral Surg Oral Med Oral Pathol 1994; 78: 761-5

26. Edwards PC, Bhuiya T, Kelsch RD. Assessment of p63 expression in the salivary gland neoplasms adenoid cystic carcinoma, polymorphous low-grade adenocarcinoma, and basal cell and canalicular adenomas. Oral Surg Oral Med Oral Pathol Oral Radiol Endod 2004; 97: 613-9.

27. Furuse C, Tucci R, Machado de Sousa SO, et al. Comparative immunoprofile of polymorphous low-grade adenocarcinoma and canalicular adenoma. Ann Diagn Pathol 2003; 7: 278-80.

28. Curran AE, Allen CM, Beck FM, et al. Distinctive pattern of glial fibrillary acidic protein immunoreactivity useful in distinguishing fragmented pleomorphic adenoma, canalicular adenoma and polymorphous low grade adenocarcinoma of minor salivary glands. Head Neck Pathol 2007; 1: 27-32.

29. Harmse JL, Saleh HA, Odutoye T, et al. Recurrent canalicular adenoma of the minor salivary glands in the upper lip. J Laryngol Otol 1997; 111: 985-7. 